\title{
Law of Success or Failure in the High Tech Driven Market - "Revenge of Success" in the Biotech, Nanotech, and ICT Industry
}

\author{
Takayama, Makoto \\ Niigata University, Graduate School of MOT; UCLA Medical School
}

Japan

\section{Introduction}

In the case of product change, it is well known that incremental product innovation is well managed by the cooperation between marketing knowledge and technology knowledge (von Hippel, 1988, 2005, 2009; Clerk and Fujimoto, 1991). If knowing marketing needs and technology seeds is enough to develop the new product, the market leader with research capability could hold the best position to become a successor in the field. The reality is different from this assumption; the successor is very often replaced (Christensen, 1997).

There is a lot of discussion on success factors in product innovation: which is the determinant for success in product innovation, technology-push or market-pull? According to technology-driven theory, the importance of technological innovation is highlighted for product innovation (Rosenberg, 1976; Freeman, 1982; OECD, 1984; Dosi. 1982, 1984, 2010a, 2010b). In contrast, market-driven product innovation has highlighted the importance of market needs or customer needs (Rothwell et al., 1974; von Hippel 1979, 1980, 2005, 2009, de Jong \& von Hippel, 2009). These discussions have not led to any sufficient conclusion. With respect to new product development (NPD), the aforementioned opposing theories have highlighted the importance of technology knowledge and market knowledge. Although the applicability of the theory depends on the respective product, it is absolutely obvious that the product is an embodiment of market knowledge and technology knowledge. In the case of novel technology emerging, technology seemed to serve as a major driving factor to introduce the relevant new product into a market. It is also well recognized that market knowledge can stimulate successful NPD. It seems to be obvious that market knowledge assists the accumulation of technology knowledge. Apparently, both technology knowledge and market knowledge are able to serve as the key factors that enhance successful NPD. If so, the market leader can keep its leading position in the market for the next generation of new products and hence the market leader cannot be easily taken over by the newcomer, even if the new product creates a new market. For continuous NPD, this assumption is true.

The concurrent engineering system is thought to be the best way to launch the next product into the market (Hammer \& Champy, 1993). For the automobile industry and the electricity industry, many authors have demonstrated the advantage of the collaboration between 
technology and the market (Ohno, 1988; von Hippel, 1988). The opposite of this finding is true. There are many examples of major players losing their strong position in the market when new products emerged. Why can't leading companies maintain the best position in the market? It seems to be related to the characteristics of the product. This problem has not yet been solved by the current discussions on NPD. In this chapter, a recent change to a product in the high tech markets such as bio, nanotech, ICT market are studied.

This work demonstrates that a strong product inhibits the NPD of a newly emerging product that will replace the existing product market in the future, furthermore, that there is no need to have the core competence for the existing market or technology. In order to demonstrate the behavior of the companies, R\&D and market analysis have been carried out. Section 2 identifies the characteristics of product and players change in the high tech industry. Section 3 analyzes the behavior of the company in the case of product change. Section 4 describes the case studies of product change at mature stage of the existing markets. Section 5 presents mechanism of success or loss. Section 6 concluded the fate leads the success or loss of each of major players in the new born high tech market like invisible hand of God. How to evade from the fate is the most important implication at the end of this chapter; all businesses, though, cannot evade from the fate of the law of success or failure.

\section{Current situations and structural problems of high tech industry management}

The market of the high tech industry is in the process of development: the whole panorama remains invisible. Little attention has been paid to idiosyncrasies of the high tech industry in terms of technology and market. While it is relatively easy to forecast future development of existing industries, this is not the case for the high tech industry. The situation is analogous to the difference between physics and biology: logical forecasts useful in existing industries do not work for the high tech industry, which is as unpredictable as the world of bio-organisms. Successful innovation and commercialization of new products or new business require a perpetual cycle of hypothesizing, verification and exploring about the products or businesses and their markets. Many enterprises have failed in high tech products or businesses because of this cycle conducted in a traditional manner. In other words, such enterprises were "revenged" by their success itself (Takayama, 2002, 2005; Takayama \& Watanabe, 2002), only wasting their money, labor and time. There is a structure that prevents the conventional methods from succeeding, and the real problem is that not only major market players but also entrepreneurs are not aware of that structure set forth in the new born markets.

\subsection{Absolute win or unavoidable loss in bio-industry businesses}

As a matter of fact, many existing major businesses have failed in seemingly promising development projects especially of innovative products or businesses. Their extensive and preceding investments for $R \& D$ or facilities, including those for establishing new laboratories or huge infrastructures, did not prevent newcomers with different backgrounds from winning their market shares. The typical feature of the investment is prioritized and authorized by top management among the high tech related industries in common. Even with knowledge of new technologies, products and markets at higher level than their competitors, majors will certainly lose under some conditions, while winning under others. As a typical case of the bio-industry market, in the applications of the recombinant DNA technique, all related firms had established bio-tech institutes under the prevailing bio-tech era 
in 1980s. This bio-tech institute boom is not only limited to life science related firms such as pharmaceutical, beer, fermentation etc. but also absolutely unrelated firms in such industries as chemical, textile, food, steel, electrical industry etc. All businesses have believed still now that establishing only institute could strike gold mine from the huge unveiled markets.

The result of the win or loss was simple. Agricultural majors have continued to win the victory by successively launch of recombinant plant. They have kept competitors out of the existing market. Only the exception was a new born market segment like blue carnation and blue rose market made by outsider Suntory. On the contrary, pharmaceutical majors could not develop any bio-pharmaceuticals by own efforts. It should be emphasized that they could not take the opportunity by introducing bio-products even at very cheap licensing fee offered by bioventure like Genentech, although business routine based on open discussion has been established in the organizational structure of every firm for a long time. Major players failed the bio-pharmaceutical market. Typical winner was Amgen that is started by spin-off researchers from Merck \& Co. Inc. in the USA and became Board Chairman of PhRMA (Pharmaceutical Research and Manufacturers in America) and actual revenue including licensees is presumed almost equivalent to the sales amount of Merck. If Merck could hold scientists in its R\&D activity, it could keep the steadfast and immovable position in the current market. Exception was catch-up type bio-products like insulin, human growth hormone. All of such catch-up type recombinant-products are marketed by strong players in the existing pharmaceutical market even if the first discovery was made by bio-venture like Genentech.

In conclusion, the fate of win or loss were opposite, as shown in Table 1: agricultural majors were successful in excluding newcomers from the recombinant plants market, while no pharmaceutical majors were able to commercialize recombinant drugs in spite of large-scale R\&D programs in dedicated laboratories.

\begin{tabular}{|l|l|l|}
\hline & Existing businesses' result & Winning business sector \\
\hline Recombinant plants & Complete Victory & Agro-business \\
\hline Recombinant pharmaceuticals & Unavoidable Loss & Pharmaceutical business \\
\hline
\end{tabular}

Table 1. Fate of major businesses in the new born market of recombinant bio-products

Meanwhile, the chemical industry, once seen as the leader in commercializing bio-products, has shown a general tendency of divestiture of bio-businesses, including the pharmaceutical business. Those new companies usually focus their resources in limited product areas. This results in cutthroat $R \& D$ competition in a small number of themes, naturally raising the share of R\&D expenditure. This in turn necessitates pursuit of large sales by focusing on lucrative products, creating a vicious circle. Owing to such structural problems set forth in high tech innovation, all chemical firms have failed NPD not only in the bio-industry but also nanotech industry, which is demonstrated in the following sanction 2.2.

\subsection{Absolute win or unavoidable loss in nanotech industry businesses}

The fate of win or loss in nanotech products was the same. All firms in the nanotech-related industry have still now been establishing nanotech institute from 1990s. Nanotech boom started in 2000 and nanotech has prevailed over the material industry. Although nanotech broadly includes biotech, pure bio industrial area should be excluded from nanotech since bio started as recombinant technology earlier than nanotech in 1970s. Based on this definition, nanotech has been mainly applied to device and material. 


\section{CPU Transistor Counts 1971-2008 \& Moore's Law}

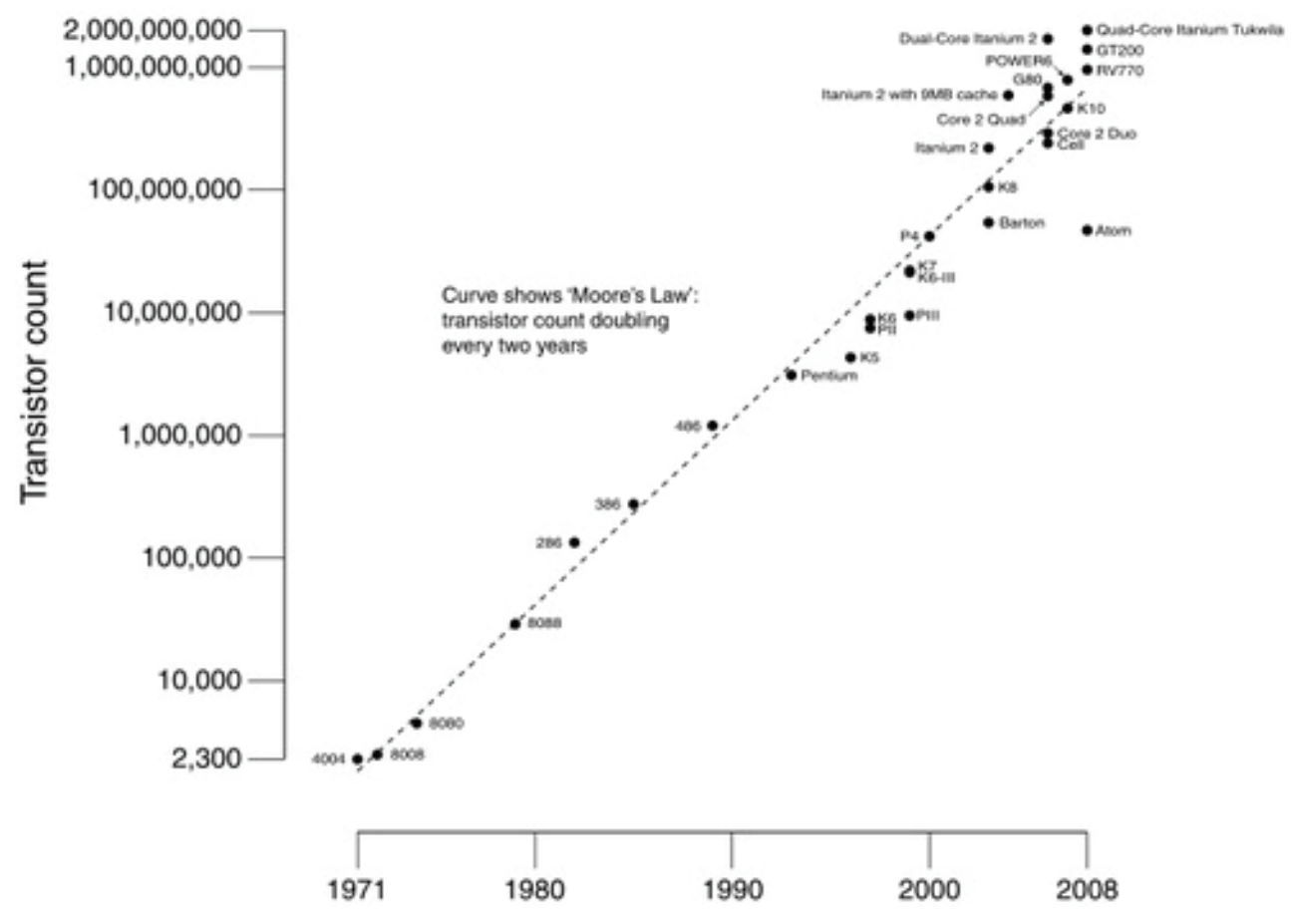

Date of introduction

Fig. 1. Moore's law from Intel's history (Intel HP)

Exemplary examples in the nanotech device market are ICT devices like semiconductor, memory etc. The most famous law in this industry is "Moore's law" (Moore, 1965 and 1996). Moore's original statement was that transistor counts had doubled every year. As shown in Figure 1, Intel has succeeded in continuous innovation by improving the performance of integrated circuit. Sustainable growth of ICT has been suspicious since small scaling limit is believed to reach in 2012. Intel is overcoming this limit by applying nanotech to integrated circuit. This clearly proves that major player could keep the position in the next market by continuous innovation.

In case of nanotech material, the situation is completely opposite to the common prediction, as below. There is no noteworthy nanotech material market except carbon nano-materials like fullerene, carbon nanotube etc. A fullerene is any molecule composed entirely of carbon, in the form of a hollow sphere, ellipsoid, or tube as shown in Figure 2. Spherical fullerenes are also called buckyballs, and cylindrical ones are called carbon nanotubes or buckytubes. Buckyballs and buckytubes have been the subject of intense research, both for their unique chemistry and for their technological applications, especially in material science, electronics. 


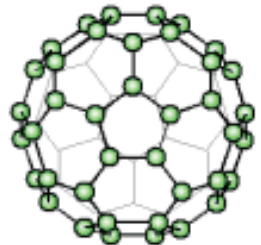

(a) $\mathrm{C}_{60}$

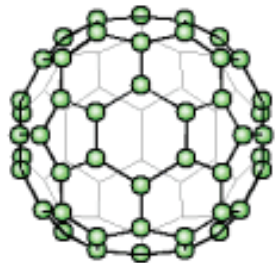

(b) $\mathrm{C}_{70}$

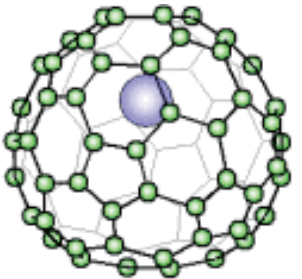

(c) La@ $\mathrm{C}_{\mathrm{c} 2}$

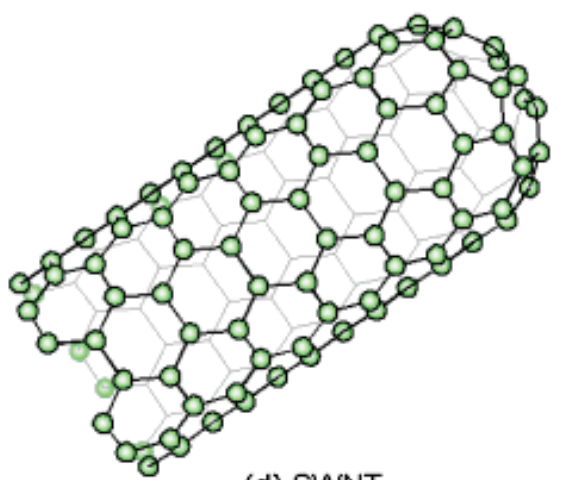

(d) SWNT

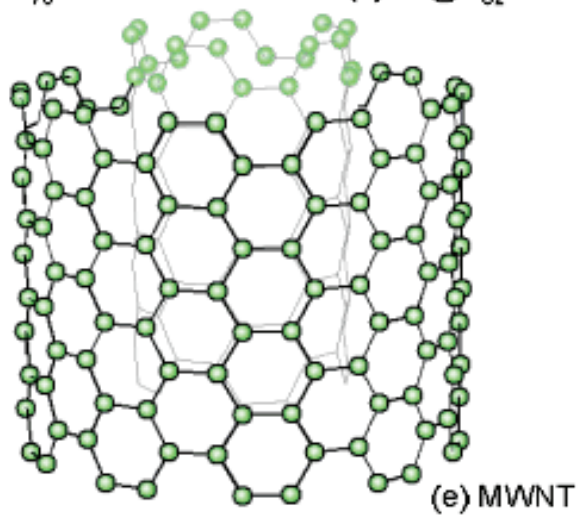

Fig. 2. Carbon nano-materials

The existence of $\mathrm{C}_{60}$ was predicted by Eiji Osawa in a Japanese magazine in 1970 (Ozawa, 1970). He noticed that the structure of a molecule was a subset of a soccer-ball shape, and he made the hypothesis that a full ball shape could also exist. His idea was merely reported in Japanese magazines. Also in 1970, R.W. Henson proposed the structure and made a model of $\mathrm{C}_{60}$ (Thrower, 1999). The evidence for this new form of carbon was very weak and was not accepted over 29-years period.

From the viewpoint of the required expertise in the chemical profile of nanocarbon, the chemical industry, once seen as the leader in commercializing nanotech products, has shown a general tendency of divestiture of nanotech businesses, although the cosmetics and textile businesses succeeded in marketing nano-materials. Major companies usually focus their resources in limited product areas. This results in cutthroat R\&D competition in a small number of themes, naturally raising the share of R\&D expenditure. This in turn necessitates pursuit of large sales by focusing on lucrative products, creating a vicious circle. The entry has not been still now made not by chemical firms. Owing to such structural problems, unavoidable loss happened like bio-industry. Mitsubishi Corporation, the largest Japanese general trading company did break into the first market entry in 2003. Mitsubishi Chemical, a chemical company in Mitsubishi group denied its market but was urged to follow a small portion of investment. In spite of such common recognition in the chemical firms, Mitsubishi Co. assured to succeed in nanocarbon materials independently from any chemical businesses (hearing from Kojima, appointed President \& CEO and then currently Chairman, and project team at Mitubishi Co., 2002). This situation is absolutely the same as in bio-tech industry. Chemical businesses denied the market potential of the new market, although they were expected to work as key players for high tech innovation. Only outsider could see the market potential. 
As summarized in Table 2, the fate of win or loss were opposite between device such as semiconductor and material like nano-carbon. IT device majors like Intel were successful in excluding newcomers from the semiconductor market, while no material businesses were able to commercialize nanocarbon materials except cosmetics and textile in spite of largescale R\&D programs in dedicated laboratories.

\begin{tabular}{|l|l|l|}
\hline & Existing businesses' result & Winning business sector \\
\hline Semiconductor & Win & IT business \\
\hline Carbon-nano material & Unavoidable Loss & General trading business \\
\hline
\end{tabular}

Table 2. Fate of major businesses in the new born market of nanotech products

\subsection{Absolute win or unavoidable loss in ICT industry businesses}

Information and Communication Technology or ICT allow users to participate in a rapidly changing world in which work and other activities are increasingly transformed. ICT can be employed to give users quick access to ideas and experiences from a wide range of people, communities, cultures and political issues. In the recent decades widespread incorporation of ICT into many tiers of business and structuring of the global economy has occurred. ICT has increased international interconnectedness and sped up the process of globalization. In conjunction with globalization and the information revolution, ICT has reshaped the workforce and business system. By increasing the speed of international communication, ICT has enabled businesses to outsource jobs, both in the manufacturing as well as white collar sectors (Rice, 2005).

In accordance with diversification of communication method, this trend, ICT accelerates the business model from mortal to click. By structuring network among everything, ICT increases the accessibility to the necessary information and decrease of the transaction cost. This feature brought forth new economical role as intermediate. Critical changes by ICT owed to the increase of utility of information and therefore caused in changes of transaction systems.

Opposite to the semiconductor business, existing businesses such as securities, retailing, advertisement, music did not take initiative for the transaction business system by using ICT, as shown in Table 3. Beyond the common expectation, all the new business systems are taken over not by outsider but also by new comers. This is the typical feature of ICT business, which is not observed in other high tech field.

\begin{tabular}{|l|l|l|}
\hline & Existing businesses' result $^{\prime}$ & Winning business sector \\
\hline Securities & Loss & Internet security business \\
\hline Retailing & Loss & Internet shopping \\
\hline Advertisement & Loss & Net businesses \\
\hline Music & Loss & Download music \\
\hline
\end{tabular}

Table 3. Fate of major businesses in the new born market by using ICT

The case in the network music business was the same. The Network Music business is a rapidly emerging new market. Furthermore, the business approach has been changed frequently in response to rapid changes in customer preferences and the constant evolution 
of technical platforms. Network Music systems are rapidly changing from one technology to another. In order to achieve optimal corporate profit, the most crucial factor should be "how to create strong customer relationships" through the network as a continuing source of network music business. Key success factors in the network music business are now understood to be the capability to continuously create new products based on the infrastructure of customer satisfaction in the network system. Before download music market, Walkman has prevailed across the world. Walkman was the strange tool because the use was limited only through earphone not by speaker. Download music player like iPod is much easier to store and select the music. Sony denied the market potential of download music at top management conference in 1999 (Idei, 2009). Furthermore, it is noteworthy that Japanese firms are most good at the technologies used in iPod. This proved that technological top tier is not sufficient for win the new market, in other words, not useful for successful launch of innovative product.

\subsection{Structural problems of high tech industry management}

These situations raise a question whether the typically research-intensive high tech industries like bio, nanotech and ICT, with by far the largest or larger R\&D expenditure in the whole industrial sector, have succeeded in innovation through high tech. In case of pharmaceutical firms, while publicizing themselves as the leaders in bioengineering for healthcare, existing companies in this field are losing the new market to newcomers, and trying to counter by expansion through M\&A, resulting in yearly changing sales ranking. Smaller enterprises are forced to focus on a limited product lines. This may bring about higher efficiency and profit for a short period, but its long-term effectiveness is questionable. The present work discusses the management of high tech businesses to show that circumstances exist:

1. where major businesses succeed in product innovation allowing no newcomers to participate in the new market

2. where they fail because of the "revenge of past success";

3. factors exist that decide the win or loss.

4. by elucidating the mechanism of the win and loss, it is demonstrated that the product development in the high tech business requires a management strategy different from that for other industry branches.

\section{Win or loss in the development of high tech products and business}

\subsection{Win or loss in the launch of high tech products}

The performance of major businesses in the development of new biotechnology-related products is shown in Table 4. All the majors in the agricultural products have successfully commercialized bio-products such as recombinant crops and remain as market leaders. The food majors have also succeeded in assimilating biotechnology for renovation of production processes and development of new products. In contrast, the pharmaceutical and chemical majors were unsuccessful in antibody formulations and other biologics, except for products earlier developed such as insulin or growth hormones in spite of almost frenzied effort, including establishment of new laboratories dedicated to bioscience. Chemical companies have also lost the potential market of nanotech products even after the winners from other fields. Situations were similar in a related area: leading manufacturers of syringed did not develop needle-free syringes used in administration of biologics. 


\begin{tabular}{|l|l|}
\hline & Expected majors' result \\
\hline Agriculture & Win \\
\hline Food & Win \\
\hline Bio-pharmaceuticals & Loss \\
\hline Antibody pharmaceuticals & Loss \\
\hline Nanotech materials & Loss \\
\hline Needle-free syringes & Loss \\
\hline
\end{tabular}

Table 4. Performance of major businesses in new markets by high tech products

Win in biotech products development seems to depend on several factors. Table 5 sets win case to loss case for clarifying market position of majors to high tech products. Situations of agricultural products and biopharmaceuticals described earlier may be analyzed in terms of a few aspects.

\begin{tabular}{|l|l|l|}
\hline & Agricultural majors & Pharmaceuticals majors \\
\hline Business result & Win & Loss \\
\hline Competition & Direct & Indirect/neutral \\
\hline New products & Replace existing products & Create new markets \\
\hline New product development & Promoted & Neglected \\
\hline
\end{tabular}

Table 5. Position of majors to high tech upcoming products

New agricultural products, such as recombinant crops, are in direct competition with existing products and will replace them as far as the advantage of the new products are maintained. This prompts the market leaders to keep their position by developing new products instead of insisting on their existing product lines. They can exploit wealth of relevant information for their competitive advantage, leaving little hope of market entry for potential newcomers. In fact, examples of successful entry by newcomers are limited to those in niche markets neglected by the majors.

Reverse is the case for bio-pharmaceuticals and antibody pharmaceuticals. Leading manufacturers of first-generation bio-products such as insulin, growth hormones started the development and launch in the market once the technology has been confirmed. As the facts described, they have immediately followed the emerging high tech itself and furthermore master the production and marketing of the bio-pharmaceuticals. In spite of core capabilities, all of majors failed in development of granulocytic proliferation factor, or the multibillion-dollar erythropoietin, antibody pharmaceuticals, which compete only indirectly with existing products or are neutral to competition, and create their own new markets as shown in Table 6. The majors neglected products development because they failed to recognize the potentially huge market size for those products (which they predicted, instead, would form only small niche markets). In other words, the majors were not willing to be competitors in the new field, thus allowing newcomers to dominate the market easily. This miscalculation was also responsible for their failure to respond to the need for marketing partners of the newcomers without established sales network, which would have meant an opportunity to seize on the new market without compromising the existing products. This is a typical case of the "revenge of success" (Takayama, 2002; Takayama \& Watanabe 2002). Amgen, a pioneer of bio-pharmaceuticals, benefited from these 
circumstances so much so that its top management provided a president of Pharmaceutical Research and Manufacturers of America.

\begin{tabular}{|l|l|l|}
\hline & $\begin{array}{l}\text { First-generation } \\
\text { bio-pharmaceuticals }\end{array}$ & $\begin{array}{l}\text { New born } \\
\text { bio-pharmaceuticals }\end{array}$ \\
\hline Business result & Win & Loss \\
\hline Competition & Direct & Indirect/neutral \\
\hline New products & Replace existing products & Create new markets \\
\hline New product development & Promoted & Neglected \\
\hline
\end{tabular}

Table 6. Position of existing majors to first-generation bio-pharmaceuticals and new born bio-pharmaceuticals

\subsection{Win or loss in starting new business system by using high tech}

As a proof of the difficulties of the entry to business system by existing players, cloud computing exhibits many examples. Cloud computing had been recognized as next wave for technology investors (Hamilton, 2008). As Cloud platforms become ubiquitous, global cloud is expected to serve as an exchange and market infrastructure for trading services, since the need for internetworking create a market oriented global cloud exchange for trading services (Armbrust etc., 2009). SPI is KFS (Key Factors for Success) in cloud computing business; SaaS, PaaS and IaaS represent Software as a Service, Platform as a Service and Infrustructure as a Service., respectively. The sygnificant role of these core comcepts can easily make out the conlusion that the most critical key success factor for the cloud business is public cloud. In spite of such common recognition for the market size, only small firms like OpSource started to provide the public cloud service, since all majors have hesitated to use cloud computing system due to immaturity of the system itself.

\section{Mode of competition as a decisive factor}

Examples described above clearly shows that the mode of competition between new and old products is a decisive factor for corporate behavior with respect to new products. Direct or indirect competition of a new product with a company's existing products determines whether the company wins or loses in launch of that particular product or start of noble business system. Since the mode of competition of a new product depends on the nature of existing products, different companies may behave in different ways even in one and the same market segment.

\subsection{Case of specified supplementary foods}

Another example of such corporate behavior can be found in the rapidly growing market in Japan of "specified supplementary foods", a class of foods which contain specific therapeutic ingredients and are approved by the Ministry of Health, Labour and Welfare based on test results on the safety and effectiveness. A major area of such foods is life style related diseases as represented by metabolic diseases including diabetes mellitus, hyperlipemia, hypertension and hyperlithemia, which are the main targeted therapeutic area of all pharmaceutical businesses. Many supplementary foods against these diseases have been 
developed by both big and small businesses, creating a market of about a trillion yen. It is predicted that "the market will more than double if the national health insurance system is modified to allow doctors to prescribe supplementary foods for prevention of adult diseases, particularly against fatigue and enhancing functions of blood vessel endothelium cells" (Nikkei Health, Jan. 28, 2005). For this purpose, the insurance system has begun to change from 2009. This is a considerable market size compared with 8,850 billion yen sales for all Japanese pharmaceuticals prescribed by physicians (mix, 2010) and 774 billion yen for OTC sold at drugstore (Yano Research Institute, 2009) in 2009.

Drug manufacturers are in the most advantageous position in this market sector with the expertise in new drug evaluation, familiarity with the Ministry's policies, and existing health food divisions that eliminate prior investments for distribution channels, as well as accumulated drug-related knowledge, experience and infrastructure that possibly bring about synergistic effects. In short, this market should be the easiest for drug manufacturers to attack. Actually, however, companies behaved as shown in Table 7. Drug manufacturers, including smaller ones, did not attempt product development, not to mention market entry. Food or drink majors behaved the same as drug majors. This is clearly not their failure but their intention. The new market was rapidly created in 2003 by catechin green tea drink of Kao, which was originally a soap company and currently a commodity major in the Japanese market. Only inexperienced firm has succeeded in entry to new born market. Similar phenomena have been observed in the American and European functional food markets. As recent topis, iPod by Apple was the same case, although the first winner in the former market failed to enter rather denied the market, as described in Section 2.3.

\begin{tabular}{|l|l|l|l|}
\hline & $\begin{array}{l}\text { Food or drink } \\
\text { majors }\end{array}$ & Drug majors & Kao, outsider \\
\hline Market entry & Loss & Loss & Win \\
\hline Mode of competition & Indirect & Indirect & Inexperienced \\
\hline New products & Create new market & Create new market & Create new market \\
\hline Product development & Hampered & Hampered & Promoted \\
\hline
\end{tabular}

Table 7. Corporate behavior in supplementary food market

The catechin was well-known as bitter ingredient of green tea and lipid-lowering function for human body. As the most popular green tea drink major, Itoen Inc. discovered canned green tea in 1985 (Itoen HP) and had kept the top market share, around 40\% for 20 years (Ishii, 2010). Drink major firms including Itouen, Suntory etc. know the mode of function of catechin for lowing lipid, they neglected as a transient boom even after Kao sold 20 billion yen after 10 months from the launch. More interestingly, all drug majors neglected the market itself notwithstanding exactly the same targeted as drugs. It is worthy of remark that winner has not held any value chain such as food or health-care channel in addition to lack of any authorized core competence for the new market.

The cases presented so far are concerned with new products that create new markets. But the same analysis can also be made for new products within existing market sectors. The same pattern of win and loss of the majors is observed in every country (Takayama, 2002; Takayama \& Watanabe, 2002; Takayama, Watanabe \& Griffy-Brown, 2002; Takayama, Takayama, 2005; Takayama 2009). Some cases are described in the following sections. 


\subsection{Case of the most competitive new product in the most competitive market}

A typical example of such cases is the antihypertensive drugs, which accounts for about $10 \%$ of the world drug market from 1990s and now forecasted to increase the share in the market. Hypertension is a kind of lifestyle-related diseases, although few symptoms, heart failure, cerebral hemorrhage, myocardial infarction and other dangerous complications are caused.

The anti-hypertensive market is almost mature in the early 2000s, because the existing products treat almost $90 \%$ of patients. According to interviews conducted by the authors, only three companies in the top 20 pharmaceut ical companies in the world maintained research activity for hypertensive drugs in 1999 and the others have been winding down this activity, although all companies reinforced research activity on anti-hypertensive drugs at least 10 years ago. Last product innovation was emergent, although the anti-hypertensive market is in the mature stage. The final products, angiotensin receptor blocker (ARB; ATII: angiotensin II receptor antagonist) were made based on the same new technology and have been launched country by country. In Japan, the first product was launched in August 1998. In hypertensive medication, there are two major products, Ca blocker (Ca) and Angiotensine Converting Enzyme Inhibitor (ACE). Since Ca shows rapid onset and sharp efficacy, it is used as the first choice for the treatment of hypertensive patients who do not have organ malfunction, such as diabetics. Although the efficacy of ACE is less than Ca and ACE has the side effect of a cough, ACE is used for older patients who are at risk from organ damage. As the final new product in this market, the first product of ARB has launched by Merck Co. in 1995 and its peak sales was, at that time, estimated around 400 million dollars in the world. After 10 years of the first launch, this new product category has replaced $\mathrm{Ca}$ antagonist, the largest product category in the existing hypertensive market (Fuji Keizai, 2010). In 2004, sales of ARB in the Japanese pharmaceuticals market has exceeded hyperlipidemia market, which was the largest product category and also the main target of specified supplementary food as described in section 4.1.

After the severe competition of new drug development from 1990s to the early 2000s, have proved to dominate the world antihypertensive market with a share over $70 \%$ for the first prescribed patients. In the struggle for this huge market involving drug manufacturers of all sizes, the majors which had product lines not in direct rivalry with ARBs, e.g. calcium antagonists, were eventual losers: they did not succeed in development, if any, of the new product, at least in a timely manner. The "calcium myth", promoted in Japan by the leaders of the antihypertensives market, which claimed the superiority of $\mathrm{Ca}$ antagonists, did not play any important role in the process. Rather, the majors fell victim to the revenge of their own success in every country (Takayama, 2002; Takayama \& Watanabe, 2002). The performance of specific enterprises is summarized in Table 8 by the top 10 companies in the world Ca market. Of the top 10 companies, nine have no ARB product and two firms with minor share did get the co-marketing right of ARB from other marketing partners. Although two companies, Takeda and Novartis, have ARB pro ducts, Takeda does not market Ca outside of Japan, and Sandoz Co. and Ciba-Geigy Co. (who are merged and became Novartis) brought ARB in 1997. Two companies, Hoechst and Astra, are developing license-in ATII products. Ten out of the top 10 companies have no self-made or self-developed products in the world market, although those products became the global mega breakthrough products in the middle of 2000s.

In contrast, most of the major producers of ACE inhibitors which are indirect competition with ARBs succeeded in product development (see Table 9) (Takayama, 2002; Takayama \& Watanabe 2002). They were able to exploit their superiority in information access for more speedy development, which prevented effectively newcomers from entering the market. 
The behavior of ACE leaders is different as demonstrated in Table 9. The positive behavior of leading companies4 for developing ARB or ACE/NEP. ACE/NEP is expected to be a superior product to $\mathrm{ACE}$, like $\mathrm{ARB}$, because it has higher potency than $\mathrm{ACE}$ and reduces the cough side effect of ACE by adding NEP inhibitor activity. Seven out of the top 10 companies are developing their own products and one company is developing a license-in product. This fact demonstrates the positive attitude of the ACE leader1 for developing ARB. The remaining two companies do not develop ARB. This is because of their strong position as first and second in the Ca market, since their total market share is approximately $47 \%$.

\begin{tabular}{|l|c|c|}
\hline Company & Market share (\%) & Development priority \\
\hline Pfizer & 33.9 & -- \\
\hline Bayer & 12.8 & -- \\
\hline Hoechst & 9.0 & Third (licensed) \\
\hline Astra & 3.7 & Fifth (licensed from Takeda) \\
\hline BASF & 2.7 & -- \\
\hline Monsanto (Searle) & 2.4 & -- \\
\hline Kyowa Hakko & 2.2 & -- \\
\hline Yamanouchi & 2.0 & -- \\
\hline Takeda & 2.0 & Ninth (licensor) \\
\hline Ciba-Geigy & 2.0 & \\
\hline
\end{tabular}

Source: World Review 1999 by IMS Health (The Pharmaceutical Market)

Table 8. "Revenge of success" to market leaders of Ca antagonists, a product not competing with ARBs

\begin{tabular}{|l|c|c|}
\hline Company & $\begin{array}{c}\text { ACE Inhibitor } \\
\text { Market share (\%) }\end{array}$ & Development priority \\
\hline Merck Co. & 31.0 & First \\
\hline Zeneca & 13.4 & Fifth (licensed from Tanabe) \\
\hline Bristol-Meyers Squibb & 10.7 & $\begin{array}{c}\text { Fourth (First as ACE/NEP } \\
\text { inhibitors) }\end{array}$ \\
\hline Warner-Lambert & 6.4 & -- \\
\hline Novartis & 5.3 & Second \\
\hline Hoechst & 3.8 & Third \\
\hline Servier & 3.7 & Second as ACE/NEP inhibitors \\
\hline Tanabe & 1.9 & -- \\
\hline Banyu & 1.8 & First \\
\hline Sankyo & 1.7 & $\begin{array}{c}\text { Eighth (licensor to European } \\
\text { companies) }\end{array}$ \\
\hline
\end{tabular}

Source: World Review 1999 by IMS Health (The Pharmaceutical Market)

Table 9. "Revenge of success" to market leaders of ACEs, a product competing with ARBs 
ARB is superior to ACE and differentiated from Ca. From a market viewpoint, ARB competes with ACE directly and replaces the ACE market. The leaders in the ACE market need to develop ARB to keep the current market position because it is obvious that ACE will be replaced once AEB is marketed. In contrast, Ca does not compete with ARB but creates a new market. The leaders in the Ca market do not need to develop ARB to keep their market position in the Ca market, as described above. Surprisingly, the leaders in the Ca market, including Japanese companies, were prohibited from the development of ARB.

\begin{tabular}{|l|l|l|}
\hline Positioning of new product & Superior & Differentiated \\
\hline $\begin{array}{l}\text { Competition with existing } \\
\text { product }\end{array}$ & $\begin{array}{l}\text { Direct competing with } \\
\text { ACE }\end{array}$ & $\begin{array}{l}\text { Indirect competition or neutral } \\
\text { with Ca }\end{array}$ \\
\hline Mode of market penetration & Replace old product & Create new market \\
\hline Attitude to NPD & Enhancing & Inhibitory \\
\hline
\end{tabular}

Table 10. Two types of new product

This finding demonstrates that a strong existing product inhibits NPD when the product creates a new market, as summarized in Table 10. The most critical reason for the failure of NPD of ARB was the underestimation of the sales forecast, since the sales forecast is basically calculated based on product strength. The company acts to increase the strength of its own product as a market winner in $\mathrm{Ca}$, insisting on the strength of its own product (Monthly Mix, April 1999). This reduces the market value of the new product, creating a new market.

\subsection{Case of innovative medical device in the old market}

New and innovative medical device technology continues to emerge every year from companies worldwide. Some of these new technologies offer vastly superior capabilities than existing technology, however acceptance of many of these new innovative and superior medical device products often encounter tremendous resistance and neglect by major market players in the marketplace, even when using the outside opinions for evaluation of the product introduction. There appear to be a neglect of emerging market. This section provides the results of a case study of needle-free injection technology from which many valuable findings were derived.

Firms competing in increasingly sophisticated technology markets have encountered a new set of challenges. Responding to customer needs is crucial for survival, while for society as a whole, there are requirements for expanding the reach of technological benefits to larger numbers of individuals. At the firm level, maximizing customer satisfaction by providing an efficient internal manufacturing system and simultaneously securing flexibility corresponding to dynamic and rapid change have become important aspects of any competitive survival strategy. As an inevitable result of too much strengthening of a specific core field, one failure often observed is an inability to quickly move into complementary or different product areas. One survival solution is co-evolution of technology products developed in such a way that external and internal firm circumstances affecting the customer are constantly considered. The question this analysis addresses is, "How do we construct an interface between core and new products in order to simultaneously maximize core competence and yet at the same time remain flexible?" 
Institutional elasticity is one mechanism for creating such a trade-off between stability and ongoing new product development. Intriguing in-depth recent case studies on Sears Roebuck, Monsanto, Royal Dutch Shell, the US Army, British Petroleum, Hewlett Packard and Sun Microsystems (Pascale et al., 2000), demonstrate that in business, as in nature, there are no permanent winners. There are just firms that either react to change and evolve, or those that get left behind and become extinct. Equilibrium is a very dangerous position for survival, and innovation usually takes place on the edge of chaos. Self-organization and emergence occur naturally. Organizations are generally more turbulent than directed. Monsanto has successfully remained on the edge of the new business front managing the trade-offs in technology co-evolution. Monsanto is well-known that the company has leading core competence for bio-technology outstandingly different from other biotech firms. Aspartame, artificial sweetner is one of famous product that is produced by comining biotech and chemical technology. Inspite of the former success in food and agricultural NPDs, it could not move beyond its core products. Owing to the failure of NPD in the biotech market, pharmaceutical division of Monsanto is merged by Pharmacia Upjohn in 2000 due to a systemic disconnect between management, technology and market signals. This clearly shows that core competence for technology is not sufficient for successive survival.

\section{Spring powered medical device - Drug Delivery Disposable sterile medication cartridge (Ampule)}
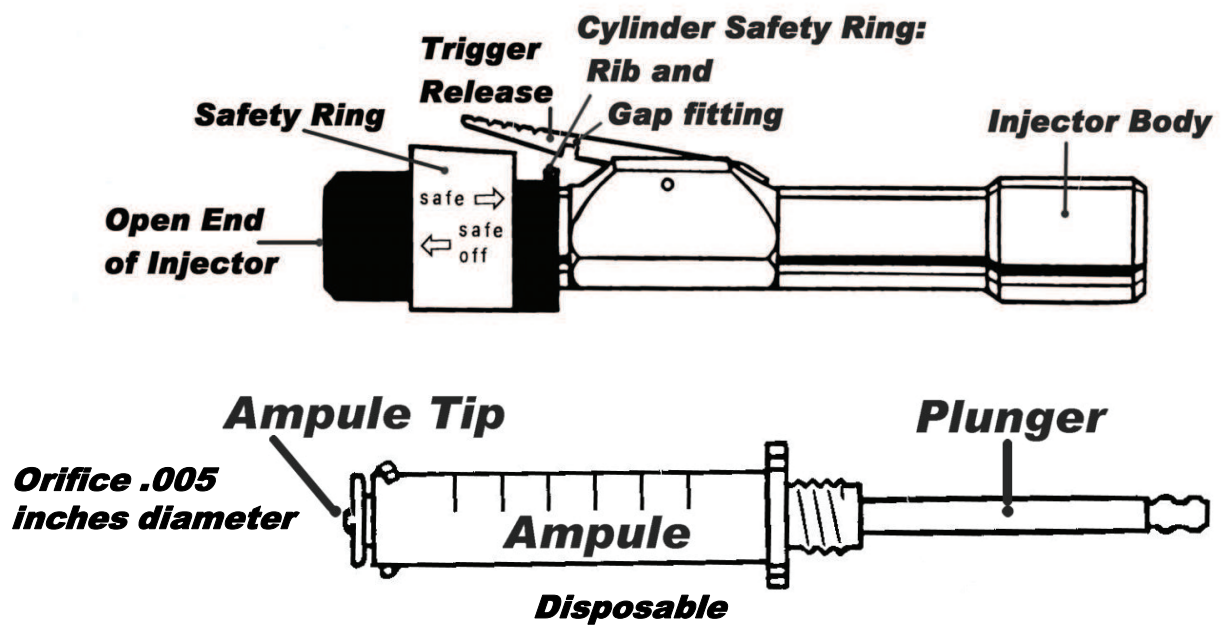

Fig. 3. Construction of needle-free injector device (Inject Co. www.injex.com)

Needle-free drug injection technology is a classic example that reveals the existence of disconnect between technology and market signals, since it is not a new idea. The early and crude beginning of this technology started over 50 years ago, and was later used by the U.S. military to vaccinate military troops in the 1960's. During the 1970's and 1980's others began to conduct extensive R\&D to improve, modify and make the technology much more consistent, reliable, pain free and with simple to use ergonomic designs. Today these needle- 
free injectors are very small pen-like and very ergonomically designed high tech instruments as shown in Figure 3 and 4.

In this section, INJEX-Equidyne Systems, Inc. is selected since it is considered one of the top two leading companies in the needle-free drug delivery industry and once selected as a partner by a Japanese largest pharmaceutical company and Pharmacia Upjohn before merger with Pfizer (personal communication with those firms). The company is more than fifteen years in business and manufactures and distributes product in over 40 countries worldwide. The company was awarded in 2004 the "medical device technology company of the year" by the well known Frost \& Sullivan technology research firm for outstanding and innovative technology as well as excellence in product quality for this industry.
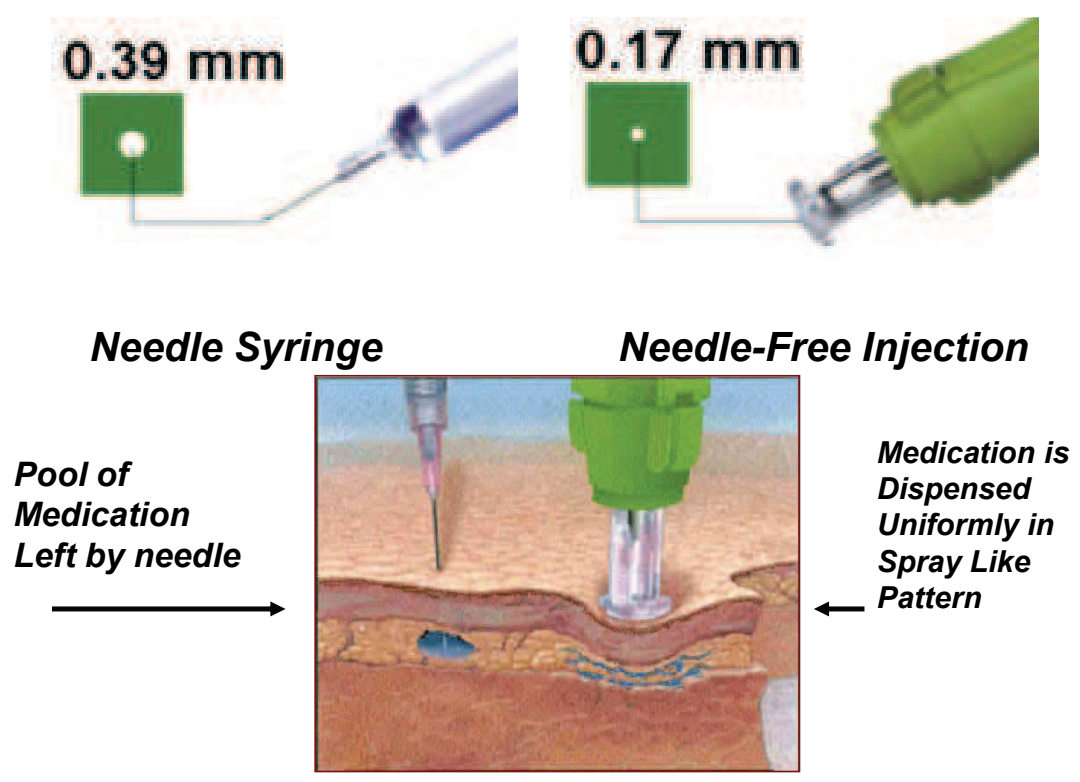

Fig. 4. Mechanism of needle-free syringe for injection through skin (Inject Co. www.injex.com)

After investigation of the issues as well as looking at consumer needs and overall market demand, social issues and other factors, we were able to develop some relevant findings, valuable information and interesting conclusions.

The major pharmaceutical and needle syringe manufacturers have generally overlooked needle-free drug delivery technology. In fact, insulin is injected with tiny-needle syringe by patients themselves every day. Although they claim that they are continuously looking for new and innovative technologies which they can adapt to their current business needs for drug delivery for waccine or pandemic disease like influenza, they have somehow not been able to see the opportunity that needle-free drug injection presents. In this case, each player in the market behave differently since their position to the new product differs each other, as described below in Table 11.

With regard to syringe majors and drug majors, competence is tied to technological core competence, this system works as a strong support for enforcing the original core field of 
individual firms. Therefore, it potentially creates inertia which keeps a firm from moving beyond its past. This rigid structure is a cause of "Revenge of Success" for major market players (Takayama, 2002; Takayama \& Watanabe, 2002; Takayama, Watanabe \& GriffyBrown, 2002ab; Takayama, 2004). This owes to a rigid scheme adhered to by product evaluation system as internal routine that is related to extensive knowledge of major market players. In case of the injector device majors including the first and second-tiered Japanese majors and the largest major in the world have evaluated this needle-free injector for about one year, conclusively, they decided not to enter the needle-free syringe market. The reason was very simple that syringe business will continue without infringement of evasion of needle-free syringe (interview to those firms).

\begin{tabular}{|l|l|l|l|}
\hline & Syringe Majors & Drug majors & End User (Patients) \\
\hline $\begin{array}{l}\text { Positioning of new } \\
\text { product }\end{array}$ & $\begin{array}{l}\text { Superior in one minor } \\
\text { business area }\end{array}$ & Differentiated & Superior \\
\hline $\begin{array}{l}\text { Competition with } \\
\text { existing product }\end{array}$ & Partially competing & $\begin{array}{l}\text { Indirect } \\
\text { competition or }\end{array}$ & Direct competition \\
\hline $\begin{array}{l}\text { Mode of market } \\
\text { penetration }\end{array}$ & Niche or littel market & Create new market & Replace \\
\hline Attitude to NPD & Neglect & Hesitate & Promote \\
\hline
\end{tabular}

Table 11. Two types of new products

The scheme of the evaluation routine, which is connected to an open network including outsiders, plays two different roles, depending product positioning of emerging technology in the existing market. (Takayama, Fukushima \& Petersen, 2005)

1. In the case of replacing or enhancing an existing product, the open network accelerates the incorporation of new product.

2. On the contrary, when creating a new product market, the open network serves to accelerate the early abandonment of poor in-house NPD and also helps to enhance the rejection of outside strategic alliance.

This practice tends to ensure over-evaluation of a potential new core product evaluation, by the major player in the industry. The open network inevitably brings to any major market player in a high tech market, superior insight and wisdom to analyze and effectively select the correct path for a major success with a new product introduction. This fate is set forth by a cardinal strategy set forth by the major market players, which allows them to compete for top-tier (Takayama, 2004). In conclusion, the fate to win or lose by the market major players is intrinsically highly influenced by "Revenge of Success" though the use of the "Inertia on the open network". In summary, this clearly indicates that open innovation does not work if the market is emerging or newly born from naught.

\subsection{Win or loss in the new born market}

Following the afore-mentioned discussion, Table 12 and Table 13 summarize mode of competition in some win cases and loss cases of existing majors in the new born markets that are caused by high tech innovation, respectively. 
In summary, win cases of existing major in the new born markets are expained by direct competition in the new born market. On the contrary, loss cases of existing major in the new born markets are characterized by indirect or neutral competition of new product to the existing product.

\begin{tabular}{|l|l|l|}
\hline & Existing majors & Mode of competition \\
\hline Cassette tape recorder & Record player & Direct \\
\hline CD player & Cassette tape recorder & Direct \\
\hline Digital camera & Camera film & Direct \\
\hline DVD & VHS manufacturors & Direct \\
\hline
\end{tabular}

Table 12. Win cases of existing majors in the new born markets

\begin{tabular}{|l|l|l|}
\hline & Existing majors & Mode of competition \\
\hline Electrics & Lamp, Mill & Indirect or neutral \\
\hline Automobile & Carriage & Indirect or neutral \\
\hline Cassette tape & Viny record & Indirect or neutral \\
\hline PC & Computor & Indirect or neutral \\
\hline Amazon & Book store & Indirect or neutral \\
\hline Net secrities & Secrities & Indirect or neutral \\
\hline Net retailing & Department store & Indirect or neutral \\
\hline Net news & Newspaper, TV & Indirect or neutral \\
\hline
\end{tabular}

Table 13. Loss cases of existing majors in the new born markets

\section{Success/failure matrix and replacement of the majors}

The importance of the mode of competition of a new product with existing products, regardless if the two are in the same market sector, has so far been amply illustrated so far. The practically deterministic situation may be summarized in a matrix shown in Table 14 . An enterprise (major or otherwise) will make serious efforts in developing a new product that may compromise existing core products. In this case, leading companies with a wealth of experience and information associated with those core products are in a highly advantageous position, so that chances for inexperienced newcomers are scarce.

\begin{tabular}{|l|l|l|}
\hline & Direct competition & Indirect competition \\
\hline Majors & Win & Loss \\
\hline Newcomers & Loss & Win \\
\hline
\end{tabular}

Table 14. Win/loss matrix

In contrast, the majors will do nothing if the new product does not compete with their existing products: they lose the opportunity because they are unaware of the market 
potential. This mechanism will lead to replacement of the majors if the new product creates its own new market, because it is dominated by newcomers and the majors that would be most familiar with the market are excluded.

\begin{tabular}{|l|l|l|}
\hline & Majors & Newcomers \\
\hline Regenerative therapy & Pharmaceutical & Fermentation, venture businesses \\
\hline Gene therapy & Pharmaceutical & Venture businesses \\
\hline Nano-biotechnology & Pharmaceutical, mechanical & Trading, venture businesses \\
\hline
\end{tabular}

Table 15. Replacement of the majors in a new market

In case of regenerative medicine, gene therapy and nano-biotech are not regarded as direct competitors to pharmaceuticals. Regeneration of the skin or neurons and regenerative therapy of heat failure are being developed by non-pharmaceutical companies as shown in Table 15. Although these techniques, as well as gene therapy and nano-biotech, will partly replace pharmaceutics in future, drug manufacturers are blind to their market potential. In the near future, pharmacuticals businesses, that insit themselves as representatives of life science business (Pisano, 2006), will lose the future huge market and new born market will be taken over by new comers.

\section{Mechanism of success and failure}

The mechanism that determines win or loss of a new product development by promoting or hampering corporate R\&D works as if by God's hand, as illustrated by the examples presented above. In the highly R\&D-intensive bioindustry, market leaders tend to concentrate on their core area, as typified by drug manufacturers. The result is competition for the top tier in a homogeneous environment, which becomes inevitably a rat race (Takayama, 2004). Winners in a market are driven by the "inertia of success", or a desire to continue to succeed, resulting in failure of recognizing the potential of new products outside their own markets (Takayama, Watanabe and Griffy-Brown, 2002a). Management of biobusinesses should take this tendency into account, which has not, however, been well recognized.

Table 16 compares some philosophical aspects of the conventional industries and bioindusty. The former deals with visible physical entities using a common language. Therefore, a competitor's logic is understandable, and individual companies compete with each other in a homogeneous situation. In contrast, the biological world is not entirely logical. Lack of a common language prevents entrepreneurs in this unforeseeable world

\begin{tabular}{|l|l|l|}
\hline & Conventional industries & Bioindustry \\
\hline Logic & Physical & Biological \\
\hline Visibility & Visible & Invisible \\
\hline Predictability & Logical & Ambiguous \\
\hline Language & Shared & Individual \\
\hline Competition & Homogeneous & Heterogeneous \\
\hline
\end{tabular}

Table 16. Philosophical aspects of the conventional industries and bioindusty 
from knowing competitors' intentions clearly. Their competition, therefore, tends to occur in a heterogeneous environment. This is reflected in the fact that none of the multifarious biotech products has become a staple commodity.

These differences have not been well recognized. From the viewpoint of conventional industries, the biobusiness is full of tedious processes that are needed before knowing how to manage the unpredictable R\&D processes and capricious markets. This accounts largely for the failure of chemical and drug majors in new biotech products.

Corporate goals is in general recognized to be based on the interests of each firm for type of product, social issues, customer preferences and demographics. The general consensus is that improvement of the product acceptance and success is mainly attributed to the company's keen understanding and a strong sense of the customer needs and general market. Surprisingly, the conclusion is exactly the opposite of the general assumptions. Those firms that have a strong interest primarily in product development have failed to keep market share. These firms successfully develop new products on the technology platform. On the contrary to such strong attention to product development R\&D and their technology, they may only catch up with the fast movement when a new market was created by other players in the different market.

\section{Conclusion}

In order to create a firm position in the new born market, strong customer relations seems to be most important influential factor to catch up with the market needs and more customer's satisfaction. Opposition to this general hypothesis, major theories are supported by those that believe that innovative product has been successfully developed by firms who have keen interest in society and human relations including employee relations.

Although these attention definitely seems to contribute to maintain core competency of the firm, most companies prefer to take the easy way to develop new product by connecting to customers and market. Afore-mentioned facts demonstrate that a strong interest in product or corporate profit cannot maintain core competence for product development especially in the case where a new market is created.

What is core competence for creating new market? The strongest core is recognized that human relations and employee relations in the business. The conclusion in this article is that the major firm has a unavoidable fate to deny any new born markers that is differentiated and hence indirectly competed with existing major's products. The law of success or failure of innovation is applicable to not only all high tech driven industry such as the biotech, nanotech, and ICT industry but also new born market that is created by continuous innovation such as new hypertensive pharmaceuticals, specified supplementary foods, down-load music etc. This owes to the neglect of a crucial message from the customers in the new born market like needle-free syringe or regeneration therapy. In spite of major's strong competitive capabilities, the success or loss of each of major players in the new born market is decided by invisible hand of God. How to evade from the fate is the most important implication at the end of this Chapter. All businesses, though, cannot evade from the fate of the law of success or failure. This owes to the neglect of a crucial message from the customers in the new born market like needle-free syringe or regeneration therapy. 


\section{References}

Armbrust, Michael; Fox, Armando; Griffith, Rean; Joseph, Anthony D.; Katz, Randy H.; Konwinski, Andrew; Lee, Gunho; Patterson, David A.; Rabkin, Ariel; Stoica, Ion; and Zaharia, Matei (2009). Above the clouds: A berkeley view of cloud computing. Technical Report UCB/EECS-2009-28, EECS Department, University of California, Berkeley

Chesbrough, H (2006). Open Business Models: How to Thrive in the New Innovation Landscape, Massachusetts: Harvard Business School Press, ISBN-10: 1422102831, Boston

Christensen, M.C. (1997). The Innovator's Dilemma. Harvard Business School Press, Boston

Clerk, K.B.; Fujimoto, T. (1991). Product Development Performance, Harvard Business School Press, Boston

Dosi, Giovanni (1982). Technological paradigms and technological trajectories. Research Policy Vol. 2 (3), pp.147-162

Dosi, .Giovanni (1984) Technical Change and Industrial Transformation, Macmillan, London

Dosi, Giovanni et al., (1988). Technical Change and Economic Theory. Printer Publishers, London

Dosi, Giovanni (2010a). Cambridge Journal of Economics Vol. 34 Issue 1, pp.173-184

Dosi, Giovanni (2010b). Knowledge Accumulation and Industry Evolution: The Case of Pharma-Biotech [Paperback], Mariana Mazzucato and Giovanni Dosi (Eds.) Cambridge University Press, ISBN-10: 052112400X, Cambridge

Fuji Keizai Co. Ltd., 2010 Data book of ethical drugs, mix, 2010/02/24 http://www.mixonline.jp/Article/tabid/55/artid/38622/Default.aspx [6 July 2010]

Gordon, E. Moore (1965). Cramming more components onto integrated circuits" pp.114-117 Electronics, Volume 38, Number 8

Gordon E. Moore (1996). Some Personal Perspectives on Research in the Semiconductor Industry, Engines of Innovation, Rosenbloom, Richard S., and William J. Spencer (Eds.), pp. 165-174, Harvard Business School Press, ISBN-10: 0875846750, Boston

D. Hamilton. 'Cloud computing' seen as next wave for technology investors. Financial Post, 04 June 2008. http://www.financialpost.com/money/story.html?id=562877 [18 July 2008]

von Hippel, E., 1979. A customer active paradigm for industrial product idea generation, Baker (ed.)

von Hippel, E., 1980. The user's role in industrial innovation, Management of Research and Innovation, Dean, B., Goldhar, J. (Eds.), North Holland, Amsterdam

von Hippel, E. (1982.) Appropriability of innovation benefit as a predictor of the source of innovation. Research Policy Vol. 2 (2), 95-116. 623

von Hippel, E. (1988). The Source of Innovation. Oxford University Press, New York

von Hippel, E (2005). Democratizing Innovation, The MIT Press ISBN-10: 0262002744

von Hippel, E (2009). Customers as Innovators: A New Way to Create Value (HBR OnPoint Enhanced Edition), Harvard Business Review, Boston

Idei, Nobuyuki (2009). Personal communication

Ishi, Junzou. (2010). President, Jan. 18, 
http:/ / president.jp.reuters.com/article/2010/01/13/A73D8B7A-FF3A-11DE-

9D22-0FC03E99CD51.php [6 July 2010]

Freeman, C. (1982). The Economics of Innovation, 2nd ed. Frances Pinter, London

Hammer, M., Champy, J. (1993). Reengineering the Corporation: A Manifesto for Business

Revolution. Harper Business, New York

IMS World Review, 1999. The Pharmaceutical Market. IMS Health, London

de Jong, Jeroen P.J. \& von Hippel, Eric (2009). Research Policy, Vol. 38 Issue 7, pp1181-1191

JPMA (Japanese Pharmaceutical Manufacturers' Association), (1999a). QEA about RED, pp.

40-41 (March)

JPMA (1999b). Hypertensive and its drugs: QEA 50 (May 1999)

Kokusai Iyakuhin Jouhou (International Drug Information) (1997) Vol. 8(25), pp. 16-19

Meyer, M.H. \& Lehnerd, A.P. (1997). The Power of Product Platforms: Building the Value and Cost Relationship. The Free Press, New York

Monthly Mix, April 1999. Trend of anti-hypertensives, pp. 36-57

Monthly Mix, September 1999. New class of ATII became the top in hypertensives to get $67.5 \%$ of the prescription rate for new patients, pp. 66-68

OECD (1984). Committee for Scientific and Technological Policy, Science, Technology and Competitiveness: Analytical Report of the Ad Hoc Group. OECD/STP (84) 26, Paris.

Ohno, T., 1988. The Toyota Production System. Productivity Press, Tokyo

Ozawa, Eiji (1970). (in Japanese) Kagaku, Vol. 25, p.854, Iwanami-shoten

Pharma Projects, 1999. V\&O Publications, Surrey, UK.

Pisano, G.P., 1997. The Development Factory. Harvard Business School Press, Boston

Pisano, G.P. (2006). Science Business, Harvard Business School Publishing, Boston

Rice, MF 2005, ' Information and Communication Technologies and the Global Digital

Divide Technology Transfer, Development, and Least Developing Countries' , Comparative Technology Transfer and Society, vol.2, no.2, pp.72-87.

Rothwell, R. et al., 1974. SAPPHO updated. Project SAPPHO, phase 2. Research Policy 3 (3), 258-291

Scrip Magazine, February 2000. Leading therapeutics in 1999. PJB Publications, London

Scrip's Yearbook, 1999. PJB Publications, Londn

Takayama, M. (2002). The true reason of failure in new products development (in Japanese), Tokyo Tosho Shuppankai, 2002.

Takayama, Makoto \& Chihiro Watanabe (2002). Myth of market needs and technology seeds as a source of product innovation, Technovation Vol. 22, pp.353-362

Takayama, Makoto; Chihiro Watanabe \& Charla Griffy-Brown (2002a). Remaining Innovative without Sacrificing Stability: An Analysis of Strategies in the Japanese Pharmaceutical Industry that Enable Firms to Overcome Inertia Resulting from Successful Market Penetration of New Product Development, Technovation 22, pp.747-759

Takayama, Makoto; Chihiro Watanabe \& Charla Griffy-Brown (2002b). The alliance strategy as competitive strategy for successively creative new product development, Technovation Vol. 22, 607-614 
Takayama, Makoto (2004). Strategy Change from Competition for Top-Tier to Competition for Uniqueness (in Japanese), Journal of Science Policy and Research Management, Vol. 19, No 1/2, 58-61.

Takayama, Makoto; Fukushima, Jim \& Petersen, Larry (2005). Why Major Needle syringe and Pharmaceutical Manufacturers not yet Accepted the Superior Needle-Free Injection Technology, Even When Using the Kansei Network?, The Global Business and Technology Association, Reading Books of the Global Business and Technology, pp.1345-1352

Takayama, Makoto (2005). Win without Fail and Fail without Win in Bio-Management, Office Automation Vol. 25, No. 4, pp. 15-21

Takayama, Makoto; Fukushima, Jim \& Petersen, L. (2005). Why Major Needle syringe and Pharmaceutical Manufacturers not yet Accepted the Superior Needle -Free Injection Technology, Even When Using the Kansei Network?, The Global Business and Technology Association, Reading Books of the Global Business and Technology, pp.1345-1352, The Global Business Association and Technology Association

Takayama, Makoto (2009). Law of success or failure in innovation, Innovation of Japanese Firm, Japan Society of Management. (Ed.), ISBN-10: 4805109319, Tokyo

Thrower, P. A. (1999). "Editorial". Carbon 37: 1677-1678

Yano Research Institute (2010). OTC Market Outlook and Strategy 2009, Tokoyo http://www.yano.co.jp/press/pdf/547.pdf [6 July 2010] 


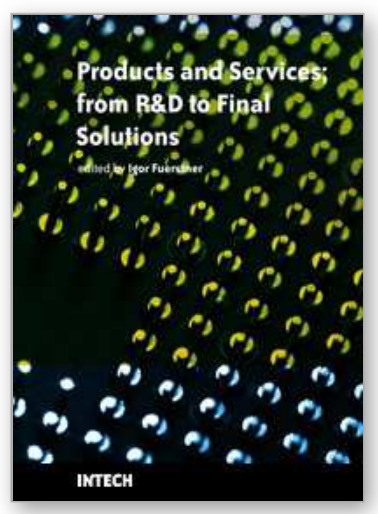

\author{
Products and Services; from R\&D to Final Solutions \\ Edited by Igor Fuerstner
}

ISBN 978-953-307-211-1

Hard cover, 422 pages

Publisher Sciyo

Published online 02, November, 2010

Published in print edition November, 2010

Todayâ€ $\mathrm{TM}^{\mathrm{TM}}$ global economy offers more opportunities, but is also more complex and competitive than ever before. This fact leads to a wide range of research activity in different fields of interest, especially in the socalled high-tech sectors. This book is a result of widespread research and development activity from many researchers worldwide, covering the aspects of development activities in general, as well as various aspects of the practical application of knowledge.

\title{
How to reference
}

In order to correctly reference this scholarly work, feel free to copy and paste the following:

Makoto Takayama (2010). Law of Success or Failure in the High Tech Driven Market - 'Revenge of Success' in the Biotech, Nanotech, and ICT Industry, Products and Services; from R\&D to Final Solutions, Igor Fuerstner (Ed.), ISBN: 978-953-307-211-1, InTech, Available from:

http://www.intechopen.com/books/products-and-services--from-r-d-to-final-solutions/law-of-success-or-failurein-the-high-tech-driven-market-and-bio-industry

\section{INTECH}

open science | open minds

\section{InTech Europe}

University Campus STeP Ri

Slavka Krautzeka 83/A

51000 Rijeka, Croatia

Phone: +385 (51) 770447

Fax: +385 (51) 686166

www.intechopen.com

\section{InTech China}

Unit 405, Office Block, Hotel Equatorial Shanghai

No.65, Yan An Road (West), Shanghai, 200040, China

中国上海市延安西路65号上海国际贵都大饭店办公楼 405 单元

Phone: +86-21-62489820

Fax: +86-21-62489821 
(C) 2010 The Author(s). Licensee IntechOpen. This chapter is distributed under the terms of the Creative Commons Attribution-NonCommercialShareAlike-3.0 License, which permits use, distribution and reproduction for non-commercial purposes, provided the original is properly cited and derivative works building on this content are distributed under the same license. 